must be fulfilled before a motion can be granted. As a result the criminal law has been provided with a workable solution by which the consequences of an ill-considered plea can be avoided.

\title{
REGULATION AND TAXATION OF HOUSE TRAILERS
}

The use of house trailers by more than one million Americans ${ }^{1}$ has created a growing problem for local government. An influx of house trailers may bring health and sanitation problems, traffic congestion, and ugly vistas to a community. Property values may be adversely affected; governmental costs are inevitably increased. In addition, it is thought that trailer dwellers make little financial, civic, or political contribution to community life. Trailers are thought to be occupied by rootless wanderers and are commonly regarded as posing threats to community interest not presented by other types of housing. The combination of all these dangers, real and imaginary, has been the source both of legitimate attempts to regulate the use and location of trailers and of hostile measures which have no similar justification. ${ }^{2}$

This comment will examine the extent to which the problems created by the mobile home have been solved in consonance with the legitimate interests of both trailer dweller and community. The discussion is divided into two areasthe regulation of trailers, and the raising of revenue to meet the social cost occasioned by the mobile-home population. ${ }^{3}$

1 America's house-trailer population has grown rapidly in the last twenty-five years. In 1930 trailer sales amounted to only $\$ 1,300,000$; by 1945 the figure was $\$ 39,000,000$, and in $1953 \$ 321,000,000$ worth of house trailers were sold. Trailers range in price from $\$ 2,800$ to $\$ 7,000$. Mobile Homes Manufacturers Ass'n, Homes for the Mobile Population (1954), and Third Annual Report (1953). Their accommodations include complete kitchen, bedroom, and sanitary facilities with tub, shower or both. Many models also contain such luxury furnishings as built-in television, built-in air-conditioning, and automatic garbage-disposal units. The average income of families buying new mobile homes in 1953 was approximately $\$ 1,100$ above the national average. Marketing Information Associates, Mobile Homes Sales Story 34 (1954). Of the total trailer population, 59 per cent of the families attend church regularly, and 75 per cent of the adult occupants are registered voters. The same survey also revealed that 63 per cent are mobile or semi-mobile occupation workers; 20 per cent are military personnel; 10 per cent are retired persons; and "all others" total 7 per cent. Mobile Homes Manufacturers Ass'n, Homes for the Mobile Population (1954).

2 While hostility to trailers is not openly admitted, its existence cannot be questioned. One locality completely excluded trailers, Commonwealth v. Amos, 30 Del. Co. (Pa.) 552 (1941) (invalidating the exclusion), by a statute also dealing with "gypsies." Municipalities have attempted to uproot trailer dwellers who had lived in the community for years. City of East Point v. Minton, 207 Ga. 495, 62 S.E. 2d 911 (1951). The city's counsel in Cady v. City of Detroit, 289 Mich. 499, 286 N.W. 805 (1939), asserted that trailer living tends to cause immorality among trailer children. In connection with the transiency provision in the Cady case, the court stated: "Ordinances having for their purpose regulated municipal development, the security of home life ... the stabilization of the use and value of property, the attraction of a desirable citizenship and fostering its permanency are within the proper ambit of the police power." Ibid., at 514, 810 (italics added). In Gust v. Township of Canton, 337 Mich. 137,59 N.W. 2d 122 (1953), a town clerk testified that the local townspeople had pressured him to eliminate the trailers within the community.

${ }^{3}$ The revenue problem became pre-eminent only after regulatory obstacles were hurdled. Until the 1930's the amount of trailer housing was negligible. The sudden boom in mobile 
An unregulated trailer population could pose substantial threats to the health of both trailer occupant and community. Strict health measures are justified by the possibility of congestion and the uncertainty as to water, sewage, cooking, bathing, and heating facilities inherent in trailer living. ${ }^{4}$ The most common health measures have been ordinances and statutes restricting trailers to trailer parks, which are required to meet stringent health requirements to qualify for the necessary license. ${ }^{5}$ None of these regulations has been held unreasonable, ${ }^{6}$ and the health menace which trailers might otherwise constitute has been successfully avoided.

Regulation of trailers has not been limited to the imposition of health standards. Additional restrictions have been engendered by hostility to the mobile home. Although community apprehension may be well-founded, its manifestations have sometimes been inequitable. One community prohibited all trailer parking in the community. The ordinance was held to violate the Fourteenth Amendment in Commonwealth v. Amos. ${ }^{7}$ Insofar as it forbade street parking the

housing during the depression years thrust upon local governments a number of serious health, sanitation, fire, and other problems which they were unprepared to meet. The immediacy of these regulatory needs at first overshadowed revenue problems. The model trailer ordinances of this earlier period dealt entirely with regulatory matters, omitting any provisions for acquiring revenue from either trailer occupants or trailer-park owners. For a striking illustration of the change in emphasis, compare Edwards, Legal Problems Created for Cities by the National Defense Program-A Report by the Committee on National Defense, Municipalities and the Law in Action 53, 89-92 (1941), with Gallagher, Municipal Ordinances and the War, A Report by the Committee on Ordinances and Ordinance Enforcement, Municipalities and the Law in Action 369, 370 (1943).

4 Egan v. City of Miami, 130 Fla. 465, 178 So. 132 (1938); Nichols v. Pirkle, 202 Ga. 372, 43 S.E. 2d 306 (1947); Palumbo Appeal, 166 Pa. Super. 557, 72 A. 2d 789 (1950). Consult Municipal Regulation and Taxation of Trailers and Trailer Camps under Pennsylvania Law, 57 Dick. L. Rev. 338 (1953).

${ }^{5}$ E.g., Mich. Stat. Ann. (Cum. Supp., 1951) c. 34, § 5.278(6), and Seattle, Wash., Ordinance No. 7627 (1954). The typical ordinance requires that trailers stay only in licensed parks. The ordinances include detailed provisions for such items as water supply, sewage disposal, park planning, plumbing facilities, electric lighting, and children's recreational areas. Some ordinances also allow a trailer to locate outside of licensed parks if the trailer is parked on the premises of an occupied single-family permanent residence, provided the trailer occupants have access to the sanitary facilities of the adjacent home. E.g., Houston, Tex., Ordinance No. 8828, § 3 (1944), Los Angeles, Cal., Ordinance No. 97876, §32.06.1(4) (1951). These ordinances have been upheld when applied to camps existing before the regulation was enacted, on the theory that a health menace will not be suffered to continue. Cloverleaf Trailer Sales Co. v. Borough of Pleasant Hills, 366 Pa. 116, 76 A. 2 d 872 (1950). Since Adamec v. Post, 273 N.Y. 250, 7 N.E. 2d 120 (1937), municipalities have been allowed to revise building regulations, making them more strict, although the higher standard may cause confiscation of a previously complying use.

- The power of the municipality, however, is limited by the state of its incorporation. If the state has pre-empted the field by statute [Richards v. City of Pontiac, 305 Mich. 666, 9 N.W 2d 885 (1943); Wood v. Peckham, - R.I. -, 98 A. 2d 669 (1953)], or the municipality is overreaching its delegated powers [Zullo v. Board? 431, 88 A. 2d 625 (1952); Devine v. Mantua Township, 28 N.J. Super. 299, 100 A. 2d 563 (1953)], its trailer regulations may be void because ultra vires.

${ }^{7} 30$ Del. Co. (Pa.) 552 (1941). 
ordinance was found to be an unreasonable interference with the normal use of the roads to which the state trailer license gave a right. ${ }^{8}$ The prohibition against parking on private property was also held to be unreasonable, although the reasoning of the court on this point is unclear. ${ }^{9}$ In light of the efficacy of the health measures already discussed, and the protection of property values and aesthetics which zoning and city planning can provide, measures totally excluding trailers from the community are difficult to justify.10 Perhaps the salient factor motivating such prohibition is a misconceived characterization of trailer occupants. It is perhaps significant that the provision tested in the $A$ mos case was part of an ordinance the first section of which related to gypsies."11

A limitation on the number of trailers in a community is defensible, however, in order to prevent a disproportionately high ratio of transients to permanent population. Provisions exist which restrict the number of trailer parks in a community to those already established..$^{12}$ Whether such legislation has been prompted by regulatory considerations or by hostility to trailers is open to question since the ordinances examined make no provision for new permits should an existing park close or the community grow.

Although most communities do not exclude trailers, ordinances which restrict the length of their stay, forcing trailer dwellers to be transients, are common..$^{13}$ Decisions upholding such ordinances rest on the assumption that trailers are not fit to serve as permanent residences; consequently, legislation which restricts the length of their stay within a community is reasonable and desirable. ${ }^{14}$

${ }^{8}$ Restrictions against long-term street parking, however, may be justified to prevent traffic hazards.

${ }^{9}$ The court, citing cases holding trailer regulations constitutional, apparently felt that since regulation was possible total exclusion was arbitrary and unreasonable.

${ }^{10}$ Trailer exclusion by any method is unquestionably a limitation on freedom of movement. The point at which such limitations become a denial of liberty in violation of the Fourteenth Amendment is not clearly defined. But a dictum in Brodnick v. Munger, 64 Ohio Law Abst. 292,102 N.E. $2 d 48$ (1951), indicates that complete exclusion of trailers is an unconstitutional restraint on freedom of mobility, and the dissenting opinion in Renker v. Village of Brooklyn, 139 Ohio St. 484, 40 N.E. 2d 925 (1942), states that a sixty-day limitation on trailer parking is unconstitutional for the same reasons. A classical definition of freedom of movement was expressed by Chief Justice Fuller in Williams v. Fears, 179 U.S. 270,274 (1900): "Undoubtedly the right of locomotion, the right to remove from one place to another according to inclination, is an attribute of personal liberty, and the right, ordinarily, of free transit from or through the territory of any State is a right secured by the Fourteenth Amendment and by other provisions of the Constitution."

${ }^{11}$ Township of Tinicum, Pa., Ordinance No. 132, $\$ 1$ (1941).

${ }^{12}$ Gust v. Township of Canton, 337 Mich. 137, 59 N.W. 2d 122 (1953), and City of Fort Lauderdale, Fla., Zoning Code $\$ 47-29$ (1947). The ordinance prohibits trailers entirely, but the city recognizes that those trailer parks in existence before the ordinance was passed have a vested right to remain. Letter of Oct. 21, 1954, from the City Attorney of Fort Lauderdale, Fla.

${ }^{13}$ E.g., Philadelphia, Pa., Trailer Park Ordinance $\$ 12$ (1942); Toledo, Ohio, Municipal Code $\$ 25-28-12$ (1951).

${ }^{14}$ Cady v. City of Detroit, 289 Mich. 499, 286 N.W. 805 (1939); Spitler v. Town of Munster 214 Ind. 75 , 14 N.E. 2d 579 (1938); Renker v. Village of Brooklyn, 139 Ohio St. 484, 40 N.E. 
The assumption that the trailer cannot serve as a permanent home is open to question. ${ }^{15}$ But assuming that trailers are inadequate as permanent dwellings, it does not follow that the trailer will cease to be a permanent abode merely because its location must be changed periodically. ${ }^{16}$ From the trailer occupant's point of view transiency provisions serve as a harassment and nothing more. The community, on the other hand, may hope to discourage trailer parking in its environs. Certainly such ordinances do not necessarily protect the health and morals of the community. Since it is only the sojourn of a particular trailer that is regulated, all trailer lots in the municipality could be fully occupied at all times despite such enactments.

It has been argued that transiency provisions are justified because a permanently located trailer is more of a financial burden on the community than a series of temporarily located trailers. ${ }^{17}$ While there is some merit to this argument, the better remedy would seem to lie in special revenue measures and not in legislatively imposed transiency.

The same result achieved by express exclusion and by transiency provisions may be reached by including trailers within the scope of conventional building codes. ${ }^{18}$ Although some building-code standards, such as foundation and chimney requirements, should not be applied to trailers, reasonable requirements designed to prevent overcrowding can properly be applied to the mobile home. There are two major types of floor-space requirements: (1) those requiring a

2d 925 (1942); Loose v. City of Battle Creek, 309 Mich. 1, 14 N.W. 2 d 554 (1944) (time limit on trailers not parked in licensed parks); Stary v. City of Brooklyn, 162 Ohio St. 120, 121 N.E. 2d 11 (1954), appeal pending U.S. S. Ct. But cf. Town of Southport v. Ross, 202 N.Y. Misc. 766, 109 N.Y.S. 2d 196 (S. Ct., 1951) (a time limitation on a trailer not parked in a licensed camp held ineffective, at least on the facts at hand, because the trailer occupant proved that he was provided with facilities superior to those in the local trailer parks). Consult Nat'l Institute of Municipal Law Officers, Automobile Trailer and Tourist Camps, c. VI, Model Ordinance, c. VIII, Ann. $\$ 11$ (1941), for an explanation that a ninety-day occupancy limitation is a necessary measure to prevent health problems caused by permanent residence in cramped or overcrowded quarters.

${ }^{15}$ Trailers have served and continue to serve as permanent homes for hundreds of thousands of persons. Moreover, health and housing agency literature of the federal government has not suggested that trailers are fit for use only as vacation vehicles. To the contrary, two bulletins provide suggestions for trailer-park regulation to make the parks suitable areas for trailer habitation, and the federal government itself has used trailers as permanent residences for defense construction workers. Consult Federal Security Agency, Public Health Service, Trailer Court Sanitation (1953), and Federal Public Housing Authority, National Housing Agency, Trailers, Bulletin for Distribution among Employees of Governmental Housing Agencies (1942).

${ }^{16}$ Since the occupation or the military status of trailer dwellers often requires the use of mobile homes, forcing such trailer occupants to move periodically does not force them into permanent dwellings.

${ }^{17}$ See Cady v. City of Detroit, 289 Mich. 499, 506, 286 N.W. 805, 807 (1939).

18 The use of building codes, an incident of the police power, is restricted to the protection of public health, safety, welfare and morals. More specifically, they are designed to prevent the construction of defective and unsanitary buildings and to reduce overcrowding. Consult 7 McQuillin, Municipal Corporations $\$ \S 24.504,24.508,24.545$ (3d ed., 1949). 
certain amount of floor space per occupant, ${ }^{19}$ and (2) those setting a minimum floor-space requirement without reference to the number of occupants. ${ }^{20}$ Most trailers can satisfy the requirements of the first type, providing there is a small number of persons living in the trailer, but the requirements of the second type ordinarily cannot be met.

Although house builders can comply with a requirement of several hundred square feet on the first floor of a dwelling house, trailer manufacturers cannot. Moreover, measures which set only a minimum space requirement with no limitation on the number of occupants do not necessarily prevent overcrowding. Unless the community purpose is to exclude trailers, ${ }^{21}$ it is more advisable to require a certain amount of floor space per occupant rather than a minimum space requirement without regard to the number of occupants.

Some communities have provided that upon expiration of a specified period of time from the date of a trailer's entry into the area it shall be classified as a dwelling for building-code purposes. ${ }^{22}$ These ordinances, which are justified on a de minimus theory that the community need not be concerned with temporary overcrowding and health problems, are nothing more than transiency provisions ${ }^{23}$ and subject to the same objections as the latter. ${ }^{24}$ Furthermore, whatever

${ }^{19}$ Chicago, nll., Rev. Building Ordinance $\$ \S 48.13$, 48.13 .2 (1949); American Public Health Association, Inc., Committee on the Hygiene of Housing, A Proposed Housing Ordinance $\$ \$ 8.1,8.2$ (1952). See, e.g., Commonwealth v. McLaughlin, $168 \mathrm{~Pa}$. Super. 442, 78 A. 2d 880 (1951) (trailers were forced to leave the community because they could not meet a buildingcode requirement of 384 square feet for the first floor). It has also been pointed out that trailers cannot meet floor-space requirements without violating vehicle restrictions. Brodnick v. Munger, 64 Ohio L. Abst. 292, 102 N.E. 2d (1951).

${ }^{20}$ Consult 7 McQuillin, Municipal Corporations $\$ 24.545$ (3d ed., 1949). The discussion below will be concerned with this type of ordinance, since it results in the exclusion of trailers.

21 That the desire to exclude trailers may prompt their exclusion by building codes was indicated with disarming frankness in People v. Gumersol, Justice Ct., Village of Orchard Lake, Oakland County, Mich. The court held that the application of building codes was justified, stating: "The advent of the house trailer is revolutionizing socjal conditions just as much as the tractor trailer has revolutionized commercial conditions. A portion of the American people are bound to become nomadic. In this event it is fitting that municipalities prepare to meet these conditions. Those that court the trailer trade should make proper provisions therefor. Those that do not should, like Orchard Lake Village, pass ordinances so drastic that it would be unprofitable to obtain a license to permit the parking of house trailers." Amer. Municipal Ass'n, The House Trailer 32, 33 (1937).

22 See Commonwealth v. McLaughlin, 168 Pa. Super. 442, 78 A. 2d 880, 882 (1951).

${ }^{23}$ In Lower Merion Township v. Gallup, 158 Pa. Super. 572, 46 A. 2 d 35 (1946), a buildingcode amendment which provided that a trailer located within the community for thirty days became a single-family dwelling for building-code purposes was tested and upheld. The court indicated, at 575 and 36 , that the thirty-day period of grace "is a fair standard by which to determine whether the use is temporary and transient, and therefore legal, or settled and fixed, and therefore illegal." Since the classification of the trailer as a dwelling is based on its use as such, and since a trailer may have been used as a dwelling for many months prior to its appearance in the locality as well as during the period of grace, it would appear that the ordinance was motivated by the duration of stay and not by the trailer's residential fitness.

${ }^{24}$ Cases cited note 14 supra. 
threats a trailer's failure to meet code standards may present exist during the period of grace.

There have been several attempts to subject trailers to building codes immediately upon entry into a community. If constitutional ${ }^{25}$ and if enforced, such ordinances would result in complete exclusion of trailers from the community.

The appropriateness of applying building codes to trailers, as of other measures excluding trailers or limiting their stay, ultimately turns on whether or not the mobile home is found to be fit as a permanent residence. ${ }^{26}$ No substantiation has yet been offered for assertions that trailers are by their nature inadequate for permanent residence. Since trailers provide housing for more than one million people, many of whom live in trailers because of the nature of their employment, widespread use of measures tending to exclude trailers has serious consequences. In the absence of evidence that less drastic measures do not adequately protect the public health and welfare, recourse to enactments prohibiting or limiting the stay of trailers should be avoided. The extreme difficulty of upsetting such ordinances because of the presumption of reasonableness ${ }^{27}$ makes it even more imperative that municipalities proceed with such measures with great caution.

Even strictly regulated trailers are not considered welcome neighbors. Local concern over property values and aesthetics and the stereotype of the trailer dweller have led to harsh application of the zoning power to trailers. ${ }^{28}$ Trailer

${ }^{25} \mathrm{An}$ attempt to make trailers subject to building codes immediately on their arrival in the community has been held invalid. Brodnick v. Munger, 64 Ohio L. Abst. 292, 102 N.E. 2d 48 (1951). The case grew out of an enforcement official's refusal to issue certain permits because trailers violated the county building code. The code itself did not refer to trailers specifically, but it was thought that the term "building" brought them within the provisions. The court reasoned that since the state enabling legislation for the local action was passed at a time when the legislature must have known both the number of trailers within the state and the futility of expecting their compliance with standard building-code provisions, if they intended the regulation of buildings to include the regulation of trailers they would have so stated. There is reason to believe the Brodnick case would not have been decided differently if the statute had specifically defined trailers as buildings. This inference is drawn from the court's reference to the freedom of mobility, the trailer's utility as a residence, and the legislature's unquestionable right to regulate trailers for human habitation.

${ }^{20}$ If trailers are in fact unsuitable as permanent dwellings, then unquestionably the police power justifies municipal exclusion and transiency regulations. If trailers are suitable such provisions would be clearly arbitrary and unreasonable. It is essential, therefore, to examine modern trailer life carefully in order to determine the reasonableness, and hence constitutionality, of exclusion and transiency ordinances.

${ }^{27}$ New Orleans Public Service, Inc. v. City of New Orleans, 281 U.S. 682 (1930), and consult 1 Cooley, Constitutional Limitations 348, 377-78 (8th ed., Carrington, 1927).

${ }^{28}$ Under modern zoning doctrine, the protection of the aesthetic qualities of a neighborhood, State ex rel. Civello v. City of New Orleans, 154 La. 271, 97 So. 440 (1923), and the conservation of property values, Hutchinson v. Cotton, 236 Minn. 366, 53 N.W. 2d 27 (1952), serve the public welfare sufficiently to constitute valid zoning practices. See Berman v. Parker, 348 U.S. 26 (1954). 
zoning has been implemented in three ways: (1) zoning ordinances which expressly restrict trailers to particular zones ${ }^{29}(2)$ ordinances which allow licensing of trailer parks only in specified zones, ${ }^{30}$ and (3) zoning laws which delegate to administrators discretionary power to place trailers in certain zones. ${ }^{31}$ All three methods have resulted in exclusion of trailers from residential zones. ${ }^{32}$ The rationale given is that trailer parks are businesses and properly belong only in commercial or industrial areas. ${ }^{33}$ The courts, however, have not suggested any differences between trailer parks and other rental housing which justify the classification of the former as commercial and the latter as residential.

The question of whether the legislative exclusion of trailers from residential zones is an improper exercise of the police power has been considered in only one case. The court concluded that the ordinance so providing was unreasonable and therefore unconstitutional..$^{34}$ The precedent value of this decision is uncertain, however, because the same result might have been reached on the ground

${ }^{29}$ E.g., Miami, Fla., Ordinance No. 1646 (1936). See Connor v. West Bloomfield Township, 207 F. 2d 482 (C.A. 6th, 1953).

${ }^{30}$ E.g., Santa Barbara, Cal., Ordinance No. 2422, § 3 (1954).

31 Chicago Rev. Code (1939) §§ 194A-2, 194A-24; Harrison, Ballard \& Allen, Plan for Rezoning the City of New York $\$ \S 1650,1651.37$ (1950).

${ }^{32}$ Huff v. City of Des Moines, 244 Iowa 89, 56 N.W. $2 d 54$ (1952). In New York sixteen cities and thirty-three villages replied to this question: "Does your zoning ordinance prohibit trailers in any certain zones? Kindly list zones where trailers are prohibited." All sixteen cities prohibited trailers in some zones. Two cities and seventeen villages excluded trailers entirely. Eight cities and eight villages excluded trailers from all residential zones. New York Conference of Mayors, Prohibiting House Trailers under Zoning Codes, Report No. 3097 (1949). City of New Orleans v. Louviere, 52 So. 2d 751 (La. App., 1951); Storm Brothers, Inc. v. Town of Balcones Heights, 239 S.W. 2d 842 (Tex. Civ. App., 1951); City of New Orleans v. Lafon, 61 So. $2 \mathrm{~d} 270$ (La. App., 1952).

${ }^{33}$ Courts have not attached significance to the classification of trailers as single-family units for building-code purposes when considering whether classification of trailer parks as commercial is proper under zoning laws. Typical trailer zoning cases state that zoning power is an incident of police power; hence the city may zone to protect public health and welfare. The court then decides, without any showing of fact, that trailer dwellers represent a threat to health and welfare in residential zones. This assertion is enough to justify the zoning. No consideration is given to the health and welfare of the trailer occupants. Conner v. West Bloomfeld Township, 207 F. 2 d 482 (C.A. 6th, 1953); Cooper v. Sinclair, 66 So. 2 d 702 (Fla. S. Ct., 1953).

${ }^{34}$ City of Sioux Falls v. Cleveland, 2d Judicial Circuit of S.D. (memorandum opinion, 1954). The decision of the trial court is being appealed. The court reasoned that it was arbitrary and unreasonable to keep trailers out of any residential zones since the remaining zones, commercial and industrial, were unsuitable for residence. The court stated that the protection of public welfare implies a duty to all of the public, including persons living in trailers.

Other decisions favorable to trailer interests have dealt only with the question of whether certain areas were correctly classified as high-class residential zones. The cases were decided without considering whether trailers should be permitted in residential zones. State v. Hayes Investment Corp., 13 Wash. 2d 306, 125 P. 2d 262 (1942); Pringle v. Shevnock, 309 Mich. 179, 14 N.W. 2d 827 (1944). 
that the trailer park involved had acquired a vested right as a prior existing use. ${ }^{35}$

Classifying trailer parks as businesses works obvious hardship on the trailer dweller. He is not permitted to live in residential areas, but must be content with raising his children in heavily traveled locations, often distant from schools, and sometimes proximal to industry. It is not suggested that trailers be allowed in all residential zones. They should, however, be permitted in at least the lowest residential zone class. ${ }^{36}$ This would afford trailer dwellers a healthy place to live without conflicting with the salutary objectives of zoning ordinances. ${ }^{37}$

\section{II}

Municipalities with a trailer population incur two additional types of expenses: the cost of trailer regulation, and general municipal expenses occasioned by the addition to the local population..$^{38}$

The power of municipalities to tax to meet regulatory expenses is well established ${ }^{39}$ and presents little difficulty. The cost of trailer regulation has

${ }^{35}$ Whether trailer parks can acquire any vested rights by prior existing use has received a variety of answers. One case indicated that a trailer park could receive a vested right to remain as a non-conforming use, but could not increase its trailer capacity. Edmonds v. County of Los Angeles, 40 Cal. 2d 642, 255 P. $2 \mathrm{~d} 772$ (1953). The general rule is that a non-conforming use will be permitted to continue but may not be enlarged or radically modified since the new use would be more harmful than the old to adjacent landowners. Cf. Lynch v. Borough of Hillsdale, 136 N.J.L. 129, 54 A. 2d 723 (1947). Consult Yokely, Zoning Law and Practice, c. XV (1953). On the other hand, one court allowed a city to enforce an ordinance prohibiting a trailer park in existence prior to the passage of the ordinance. Midgarden v. City of Grand Forks, N.D. - 54 N.W. 2 d 659 (1952). The court completely disregarded any vested rights involved, holding that to retain the park the operator must make a specific showing that the land is unsuitable for permanent residential use. It has also been decided that a trailer-park license could be denied to an existing park when an intervening zoning ordinance prohibited trailer parks in that zone. Michaels v. Township Committee of Pemberton Township, 3 N.J. Super. $523,67 \mathrm{~A}$. $2 \mathrm{~d} 324$ (1949). It was the court's view that the license should be withheld to prevent subversion of the zoning ordinance.

${ }^{36}$ If such zoning is not in consonance with the city plan, then the plan should be changed. A city plan might provide that a section of the town be limited to trailer use. Such an area should abut residential areas, and uses prohibited in the latter should also be forbidden in the trailer area.

${ }^{37}$ Although the exclusion of trailers from residential zones in multi-zone cities would appear to be unwarranted, the complete exclusion of trailers from small, entirely residential suburbs is defensible. In such localities an influx of trailers would substantially alter the community character. No court has yet upheld one-zone zoning. Dowsey v. Village of Kensington, 257 N.Y. 221, 177 N.E. 427 (1931); Proffett v. Valley View Village, 123 F. Supp. 339 (N.D. Ohio, 1953). Recent approval of zoning for aesthetic purposes, however, may be broad enough to permit one-zone zoning in some localities. See Berman v. Parker, 348 U.S. 26 (1954).

${ }^{38}$ The costs of added police and fire protection, sewage and garbage disposal, local roads, maintenance, and public education are all natural incidents of any kind of population increase. For an extensive discussion of school overcrowding due to trailer children consult American Municipal Association, House Trailer Regulation, Report No. 147, 24-25 (1951). See Edwards v. The Mayor and Council of the Borough of Moonachie, 3 N.J. 17, 26, 68 A. 2d 744,748 (1949).

${ }^{39}$ E.g., Henry v. Parrish, 307 Ky. 559, 211 S.W. $2 d 418$ (1948); and consult 38 Am. Jur., Municipal Corporations \$347 (1941). 
usually been met by the imposition of license fees. ${ }^{40}$ Although at least part of the cost may be passed on to the trailer occupant, the fee is most often levied directly on the trailer-park operator. The varying methods used are yearly fixed sums, ${ }^{41}$ fees per unit of parking space, ${ }^{42}$ and fees per month based on occupancy. ${ }^{43}$ The validity of such license fees cannot be attacked by merely alleging their amount; it must be shown that there is no reasonable relation between the amount of the fee and the cost of regulation. Absent this, substantial charges have been upheld. ${ }^{44}$

The more difficult problem of securing reimbursement from trailer dwellers for the expense they represent to the community as a segment of the local population has not been so successfully dealt with. This difficulty persists although courts have often indicated that since trailer dwellers participate in local benefits they should bear a proportionate share of the expense. ${ }^{45}$ The problem

${ }^{40}$ E.g., Los Angeles, Cal., Ordinance No. 97,876, $\$ 4$ (1951); Toledo, Ohio, Municipal Code $\S 25-28-4$ (1949); Houston, Tex., Ordinance No. 8828, \$16 (1944); Seattle, Wash., Ordinance No. $7627, \S 2$ (1954). The power to make the trailer occupant, or the trailer-park owner, pay for the costs of regulation of trailer parks by means of a license fee has been held a valid adjunct of the power to regulate trailers generally, e.g., Michaels v. Township Committee of Pemberton Township, 3 N.J. Super. 523, 67 A. $2 d 324$ (1949). Authority for the power to regulate generally is discussed in note 4 supra.

${ }^{41}$ City of Chicago v. Schall, 2 IIl. 2d 90, 116 N.E. 2d 872 (1954) (yearly license fee of $\$ 500$ on a trailer park upheld).

42 White v. City of Richmond, $293 \mathrm{Ky} .477,169$ S.W. 2d 315 (1943) (license fee of $\$ 5.00$ per trailer parking space in trailer parks upheld).

${ }^{43}$ E.g., Houston, Tex., Ordinance No. 8828, $\$ 16$ (1944), provides for a $\$ 0.25$ per week fee per trailer payable by the trailer-park operator. The park operator is directed to collect the fees from his trailer tenants, and is reimbursed for this effort by being allowed to retain 25 per cent of the fees collected. To insure proper remittances the park owner must post an indemnity bond of $\$ 1,000,000$.

${ }^{44}$ City of Chicago v. Schall, 2 Ill. 2d 90, 116 N.E. 2d 872 (1954); White v. City of Richmond, $293 \mathrm{Ky} .477,169$ S.W. 2d 315 (1943). Only two fees for regulatory purposes have been successfully attacked, and one of these was voided because the fee was a disguised property tax administered in contravention of a state statute. County Comm'rs of Anne Arundel County v. English, 182 Md. 514, 35 A. 2d 135 (1943). In County Board of Supervisors of Fairfax County v. American Trailer Co., 193 Va. 72, 68 S.E. 2d 115 (1951), a regulatory fee was invalidated because the amount unreasonably exceeded the cost of regulation. The disparity between the fee and the cost of regulation was so great that the court did not find it necessary to define carefully the limits of reasonableness. There was clear evidence in the case that county expenditures for trailer regulation were almost nil, whereas the fee for one park was more than $\$ 16,000$ for one year.

The reasonable costs of regulation are not easy to determine. It involves a cost allocation of salaries, equipment, supplies, and general overhead expenses. Since accurate allocation of regulatory expenses is almost impossible, the burden of proving that the tax bears no reasonable relation to the regulatory expense is difficult to discharge. Regulatory expenses include those expenses necessary to cover all regulation, whether or not specifically provided for in the licensing ordinance. City of Texarkana v. Hudgins Produce Co., 112 Ark. 17, 164 S.W. 736 (1914).

${ }^{45}$ E.g., Edwards v. Mayor and Council of Borough of Moonachie, 3 N.J. 17, 68 A. 2d 744 (1949); Streyle v. Board of Property Assessment, 173 Pa. Super. 324, 98 A. 2d 410 (1953). The Mobile Home Manufacturers Ass'n, in the interest of reducing local antagonism toward 
is most acute in those local governing units restricted to the use of property taxes to provide general revenue. ${ }^{46}$ The alternatives available to such a municipality are (1) classification of house trailers as personal property with assessment to the trailer owner, and (2) classification of house trailers as real property with consequent assessment of their value to the trailer-park owner. ${ }^{47}$

A personal property tax on trailers is possible, but such a levy would prove impractical and expensive. It would involve a separate tax assessment of each trailer entering the community. Moreover, since the states or municipalities cannot tax property which has no situs within the state ${ }^{48}$ the revenue yield would be reduced and tax assessment complicated.

Attempts at classification of trailers as real property ${ }^{49}$ with assessment of their value ${ }^{50}$ to the trailer-park owner have not been upheld. In Stewart v. Carrington $^{51}$ an assessed valuation of taxpayer's trailer park was increased by $\$ 13,400$ on the basis of twenty-eight trailers located on the property on the assessment date. The court held the valuation improper, reasoning that since the real property assessment statute provided for assessment as of a particular day each year ${ }^{52}$ it connoted that the location of the property must have a certain degree of permanence. ${ }^{53}$ The decision indicated, however, that trailers could, if attached to the realty, achieve the permanency required by the

trailers, has taken the position that trailer owners should bear their share of community expenses. Mobile Homes Manufacturers Ass'n, Homes for the Mobile Population (1954).

${ }^{46}$ Municipalities have only that power to tax delegated to them by the state. People $v$. Besley \& Co., 353 III. 472, 187 N.E. 461 (1933). The power to tax real and personal property does not include the power to tax privileges. Ex parte Ferguson, 59 Miss. 13 (1881). Consult 16 McQuillin, Municipal Corporations $\$ 44.41$ (3d ed., 1950).

17 It is well settled that realty taxes on land and permanent attachments thereto may be levied against the landowner irrespective of whether he owns the permanent attachments. State v. Kirchner, 185 Okla. 129, 90 P. 2d 1055 (1939); French v. Golston, 105 Colo. 578, 100 P. 2d 581 (1940).

48 Semple v. Commonwealth, 181 Ky. 675, 205 S.W. 789 (1918); Brock \& Co. v. Board of Supervisors of Los Angeles County, 8 Cal. 2d 286, 65 P. 2d 791 (1937).

${ }^{49} \mathrm{~A} 1949$ survey of New York cities and villages revealed that of the thirty-three municipal corporations answering, nineteen assessed house trailers as real property and twenty-three levied the tax against the park owner. New York Conference of Mayors, Practices in Assessing House Trailers, Report No. 3094 (1949).

${ }^{50}$ Real property taxes are based on the estimated market value of land and permanent attachments thereto. Since house trailers are ordinarily not permanently attached to the land, their resale value will not enhance the value of the land on which they are located. The meaning of "permanent attachment" with reference to trailers is discussed subsequently in this comment.

51203 N.Y. Misc. 543, 119 N.Y.S. 2d 778 (S. Ct., 1953). An earlier trial-court decision, Mason Appeal, $75 \mathrm{~Pa}$. Dist. \& Co. 1 (1950), held invalid a municipal assessment of trailers as realty. See note 62 infra.

52 N.Y. Tax Law (McKinney, 1951) §9, amended by N.Y.L. (1954) c. 509, §1.

${ }^{53}$ All the trailers in question had remained on wheels and consequently fell below the necessary standard of permanence set by the court. 
statute and therefore could be taxed as real property. ${ }^{54}$

Whereas the Stewart case used physical evidence of permanence as the basis for classification of trailers as realty, Streyle v. Board of Property Assessmenti5 suggested a different criterion. A realty assessment was there invalidated because the trailer occupants did not intend to remain permanently on the land..$^{56}$ The trailers involved were located in Pittsburgh, which has an ordinance prohibiting the conversion of trailers to realty by removing their wheels or affixing them permanently to the land. The permanent-attachment test could not be applied because of this ordinance. The court's finding that the park occupants had no intention to remain permanently ${ }^{57}$ apparently indicates that if an intention to remain permanently had been shown, the trailers could have been taxed as realty notwithstanding the absence of actual permanent attachment. This test prevents unfair long-term realty tax assessments as does the permanentattachment test, but it complicates the tax assessor's job since he must make an estimate of the subjective fact of intention.

The Streyle case does not make clear the required duration of permanency. Both the Streyle and Stewart cases, however, suggest that under certain conditions a trailer may properly be assessed as realty regardless of its classification for other purposes. ${ }^{58}$

The results in the Stewart and Streyle cases seem correct. Although not made explicit in the decisions, the justification for the use of some permanence standard in testing the validity of trailer assessments lies in the unfairness which

${ }^{54}$ Stewart v. Carrington, 203 N.Y. Misc. 543, 545, 119 N.Y.S. 2d 778, 781 (S. Ct., 1953). This dictum followed the decision in Herzog v. Miller, 170 N.Y. Misc. 1063, 11 N.Y.S. 2d 572 (S. Ct., 1939), which upheld an increased assessment of lessor's realty due to the inclusion of a lunchwagon which the lessee had put on the property. The wagon was on a permanent foundation and the classification of the wagon as real property was approved notwithstanding its treatment as personal property between lessor and lessee and the possibility that it would be removed upon termination of the lease.

55173 Pa. Super. 324, 98 A. $2 d 410$ (1953).

${ }^{56}$ The reasoning of the court was as follows: trailers with wheels are vehicles; vehicles are not realty; ergo, house trailers must be treated as personal property. The court, however, indicated that the vehicle classification was not the primary reason trailers could not be taxed as realty. "The question whether the vehicles were assessable as real estate in the present case depends upon the intention of the parties in that regard." $173 \mathrm{~Pa}$. Super. 324, 327, $98 \mathrm{~A}$. 2d 410,412 (1953).

${ }^{57}$ Some of the trailer dwellers involved in this case were University of Pittsburgh students who intended to remain in the park until they completed their college education. According to the court, the intention to remain for this period of time is not sufficient to be called an intention to remain permanently. Cf. Herzog v. Miller, 170 N.Y. Misc. 1063, 11 N.Y.S. 2d 572 (S. Ct., 1939), discussed in note 54 supra.

${ }^{58}$ Trailers have been classified variously in different contexts: as vehicles under state vehicle

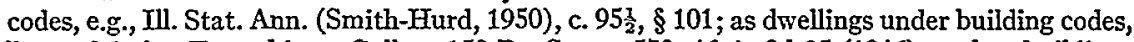
Lower Merion Township v. Gallup, 158 Pa. Super. 572, 46 A. $2 d 35$ (1946); and as buildings in a suit for payment under a life-insurance contract clause giving double indemnity for death caused by a burning building, Aird v. Aetna Life Ins. Co., 27 F. Supp. 141 (W.D. Tex., 1939), aff'd sub nom. Aetna Life Ins. Co. v. Aird, 108 F. 2d 136 (C.A. 5th, 1939). See Herzog v. Miller, 170 N.Y. Misc. 1063, 11 N.Y. S. 2 d 572 (S. Ct., 1939), discussed in note 54 supra. 
might result in its absence..$^{59}$ Real property taxes are levied annually on the basis of assessed valuation for the tax year. House trailers, on the other hand, seldom remain in one place for the full tax period. In the absence of a permanence test, therefore, a park owner might be required to pay a tax bill based in part on the valuation of trailers which, though parked on his lot on the assessment date, left shortly thereafter. In the Sireyle case, for instance, one of the trailers assessed left the day after the assessment, and the average stay of trailers in the park was six months. Unless during the year other trailers replace those assessed, the park owner would be unable to pass the tax to his tenants through rentals. ${ }^{60}$

The use of both the "attachment" and the "intention" rule is therefore important to prevent unfairness. Whenever there is permanent attachment the trailers should be taxed as realty regardless of the parties' intentions. In the absence of permanent attachment, however, the intention of the trailer dweller to remain permanently should be sufficient basis for realty tax assessment. ${ }^{61}$

Realty taxes on house trailers may have a significant tangential effect. If the trailer-park ovener defaults in his tax payments, a lien may attach to the house trailer. Creditors of the trailer owner may thereby lose priority to the municipality. ${ }^{62} \mathrm{If}$, however, state homestead laws prevent all liens except tax liens from

${ }^{59}$ The amount of the assessments may be extremely large. In Streyle v. Board of Property Assessment, $173 \mathrm{~Pa}$. Super. 324, $98 \mathrm{~A}$. 2d 410 (1953), for example, the defendant's park assessment was raised from $\$ 3,400$ to $\$ 24,900$ because of the twenty-one trailers parked on the land.

${ }^{60}$ Assessments not based on a permanency test also would result in forcing the park owner to bear a disproportionate share of the community expenses. It is true that property taxes are not based on the cost a particular property owner represents to the community, but the assessment of all trailers as realty involves statutory construction which would most probably be justified by the expense which a trailer represents. Consult Stewart v. Carrington, 203 N.Y. Misc. 543, 119 N.Y.S. 2d 778 (S. Ct., 1953). Since the justification falls if the trailer does not remain for an extended period of time a permanency test is essential.

${ }^{61}$ It must be noted that both tests use language found also in the law of fixtures. The use of the flexible "intention" and "permanent attachment" rules of fixtures doctrine might obstruct taxation of trailers properly taxable as realty and for this reason an interpolation of fixtures reasoning into the Stewart and Streyle tests should be avoided.

The law of fixtures deals with lessor-lessee and bona fide purchaser problems which have no relevance in deciding whether trailers are realty for the purpose of tax laws. If, for example, landlord and tenant agreed that a permanently attached trailer could be removed by the tenant at the expiration of his twenty-year lease, under the law of fixtures the trailers would be personalty because there was no intention to attach permanently. This result makes sense in a litigation between lessor and lessee over ownership of the trailer. It does not follow, however, that taxing authorities should be shackled by this private agreement if the tests suggested above have been met. Cf. Herzog v. Miller, 170 N.Y. Misc. 1063, 11 N.Y.S. 2d 572 (S. Ct., 1939). Although it appears that fixtures doctrine is irrelevant in determining what is real property for tax purposes it has been used in this connection. See Mason Appeal, $75 \mathrm{~Pa}$. Dist. \& Co. 1 (1951), which, although not relying on fixtures law for the invalidation of an assessment, discussed it at length.

62 Cf. Collector of Taxes v. Revere Building Inc., 276 MIass. 576, 177 N.E. 577 (1931), and consult $51 \mathrm{Am}$. Jur., Taxation $\S 1010$ (1944). 
attaching to trailers used as residences, ${ }^{63}$ the rights of creditors of the trailer owner will not be affected.

A state-wide legislative approach has been utilized in an attempt to solve the general expense problem. ${ }^{64} \mathrm{~A}$ Michigan statute provides that trailer parks shall pay a license fee based on park acreage, plus an additional amount each month for trailer lots occupied during the month. The amount netted from the acreage fee is used to defray regulatory expenses, while the funds from the monthly tax are distributed to local units for use as general expense revenue. ${ }^{65}$

The statute thus provides an adequate formula for assuring trailer contribution for local benefits, and the park operator is protected against unfairness. Collection expenses are small since both regulatory and general expense revenue are provided in the same manner. The assessment difficulties of a real property tax are avoided, and the effective sanction of license revocation is included. Such

${ }^{63}$ Trailers have been held to come within state homestead laws. In Clark v. Vitz, 190 S.W. 2d 736 (Tex. Civ. App., 1945), a trailer owner was granted a homestead exemption against creditors attempting to levy execution on a house trailer placed on a permanent foundation and used as a den. A later Texas case, Gann v. Montgomery, 210 S.W. 2 d 255 (Tex. Civ. App., 1948), denied a homestead exemption because the trailer was encumbered with the lien before it became the owner's homestead. In a separate concurring opinion Justice Speer observed, "The nature of the structure claimed as a home is of no consequence, whether it be a mansion, hovel, tent or auto trailer." Ibid., at 260. Accord: In re Foley, 97 F. Supp. 843 (D. Nebr., 1951) (house-trailer owner held entitled to the full benefit of Nebraska's Homestead Law, which provided for freedom from forced sale or judgment execution).

${ }^{64}$ E.g., Minn. Stat. (1953) cc. 327.16(3), 327.17.

${ }_{65}$ Mich. Stat. Ann. (Cum. Supp., 1951) c. 34, $\$ 5.278$ provides an elaborate system of trailerpark regulation and licensing, as well as for a fee on the park operator of $\$ 1.50$ per trailer per month. The fee is not levied for ninety days on trailers bearing license plates from states other than Michigan, unless one of the occupants of such a trailer is gainfully employed in Michigan. The funds from the fees collected are distributed as follows: $\$ 0.75$ to the local school board or district; $\$ 0.50$ to the local county; and $\$ 0.25$ to the local municipality. A municipal ordinance establishing a fee similar to the Michigan system was held constitutional in Edwards v. Borough of Moonachie, 3 N.J. 17, 68 A. 2 d 744 (1949), but the court warned that such a tax could not be confiscatory in amount. Consult generally $38 \mathrm{Am}$. Jur., Municipal Corporations $\$ 328$ (1941), on the constitutionality of license fees on businesses and occupations, and see Wright v. City of Peabody, 118 N.E. 2 d 68 (Mass., 1954). These taxes have usually been levied on the trailer-park operator, and there is doubt of their constitutionality when assessed directly against the trailer occupant. In the only test of such a measure, Kelly v. City of San Diego, 63 Cal. App. 2d 638, 147 P. 2d 127 (1944), a fee of $\$ 0.10$ per day was held void because there was no basis for discrimination between trailer dwellers and other transients in hotels and lodging houses. In this particular case the trailer-park operator also paid license fees channelled into the city's general expense funds. The resulting discrimination was that in trailer parks both landlord and tenant paid for the transients' cost to the community, but landlords, only, in permanent buildings pay taxes to defray local expenditures occasioned by their tenants. The court left open, however, the question of whether there would be discrimination if the park owner had not already paid an amount in addition to property taxes for general revenue purposes. In this connection it should be noted that whereas the presence of a hotel or lodging house would be reflected in a realty assessment the same would not be true of trailers. Refer to note $\mathbf{5 0}$ supra. 
a method of taxation takes cognizance of trailer mobility ${ }^{66}$ and will provide adequate revenue for local government without imposing an unfair burden on trailer-park owners.

66 According to Mobile Homes Manufacturers Ass'n, Homes for the Mobile Population (1954), the average trailer dweller changes his location about once each year. Since this figure includes long-term occupancies it is probable that a majority of trailers move about with much greater frequency than the average figure indicates.

\section{CUMULATIVE VOTING-REMOVAL, REDUCTION AND CLASSIFICATION OF CORPORATE BOARDS}

Notions of corporate democracy, particularly strong in the late nineteenth century, led to the introduction of cumulative voting as a means of securing representation on boards of directors to significant minorities. ${ }^{1}$ The intention was to prevent a faction controlling a simple majority of the voting shares from electing the entire board through the prior "straight-voting" method."

There are two types of cumulative voting provisions- "mandatory" and "permissive." 3 Permissive statutes leave the corporation free to ignore cumulative voting. ${ }^{4}$ Wherever the provisions are made mandatory by constitution or statute, however, the policy behind cumulative-voting legislation casts suspicion on several techniques which majorities have employed to dilute or eliminate its effect: especially, the removal of a director, reduction of the number of directors, and classification of the board. The conflict between such techniques and the policy embodied in mandatory cumulative-voting provisions forms the subject matter of this comment. 5

Mr. Joseph Medill, chief proponent of the Illinois constitutional cumulativevoting provision, stated:

The object of the section is simply to protect the rights of stockholders in incorporated companies-to protect the right of every stockholder, and to prevent the

${ }^{1}$ For a comprehensive study of voting consult Williams, Cumulative Voting for Directors (1951). "Cumulative voting is the privilege, where several directors are to be voted for at the same time, of casting votes for the whole number of shares held, multiplied by the number of directors to be elected, for one candidate, or distributing the votes among part of the vacancies to be filled. ..." Ballantine, Corporations $\$ 177$ (Rev. ed., 1946). The formula for determining the number of shares needed to elect a given number of directors under cumulative voting is: the number of voting shares at the meeting times the number of directors desired to elect, divided by the total number of directors to be elected plus one.

2 If nine directors are to be elected, the majority group under straight voting will cast its votes, one vote per share, for each of nine men, and these men will be elected.

${ }^{3}$ For a list and discussion of both the permissive and mandatory states, consult Williams, op. cit. supra note 1 , at 7-9.

${ }^{4}$ Maddock v. Vorclone Corporation, 17 Del. Ch. 39, 147 AtI. 255 (1929).

5 The most important mandatory states are: Ill. Const. Art. XI, §3; Mo. Const. Art. 11, § 6; Pa. Const. Art. 16, § 4; Cal. Corp. Code Ann. (1953) § 2235; Mich. Stat. Ann. (1951) c. $195, \S 21.32$ and c. $197, \S 21.301$; Ohio Rev. Code (Baldwin, 1953) $\S 1701.58$. 